\title{
Effect of processing of cereals on rumen fermentation, digestibility, rumination time, and firmness of subcutaneous fat in lambs
}

\author{
By E. R. ØRSKOV, C. FRASER AND J. G. GORDON \\ Rowett Research Institute, Bucksburn, Aberdeen AB2 ${ }_{9} S B$ \\ (Received 4 May I973 - Accepted 28 September 1973)
}

\begin{abstract}
I. The effects of processing cereals on aspects of rumen metabolism, physiology and pathology were investigated in five experiments with lambs. Three experiments studied the effects of diets containing loose whole, pelleted whole or pelleted rolled barley on rumen volatile fatty acid ratios, rumen $\mathrm{pH}$ and digestibility. In a $4^{\text {th }}$ experiment the effects, on the same measurements, of pelleting whole barley, maize, oats or wheat compared to feeding the whole grains in the loose form were studied. The firmness of subcutaneous fat was measured in two of these experiments when injections of cyanocobalamin or hydroxycobalamin were given and in one experiment when the diets were supplemented with two levels of cobalt. In a 5 th experiment, the effect on rumination time of pelleting whole barley compared to feeding loose whole grain was assessed.
\end{abstract}

2. When the diet contained whole barley in a loose mix and also when it contained whole maize, oats or wheat, the proportion of acetic acid in the rumen fluid was significantly increased and that of propionic acid decreased in comparison with the proportions observed when the pelleted diets were offered.

3. The $\mathrm{pH}$ of the rumen liquor was not significantly changed by feeding pellets based on rolled or whole barley, but when barley, maize, oats or wheat was given in loose form, there was an increase in the $\mathrm{pH}$ by about $\mathrm{I}$ unit in comparison with the pelleted diets. This increase in $\mathrm{pH}$ was, for all cereals, associated with complete elimination of ruminitis which, except for the oat diet, was always apparent with the pelleted feeds.

4. In general the digestibilities were not affected greatly by processing and in two experiments there were no significant differences. In one experiment pelleted whole barley was better digested than pelleted rolled barley. In another experiment the digestibility of barley was slightly greater when it was fed whole and loose compared to pelleted, while the digestibility of whole wheat was less than that of pelleted wheat. The mean digestibilities of organic matter for barley, maize, oats and wheat were $0.79 \mathrm{r}, 0.832,0.687$ and 0.846 respectively.

5. Neither injections of vitamin $B_{12}$ nor cobalt supplementation of the diet had any effect on the firmness of subcutaneous fat. Feeding diets containing loose whole barley increased the firmness of the subcutaneous fat, and this was associated with a decrease in the proportion of propionic acid in the rumen fluid.

6. The feeding of loose whole barley instead of pelleted whole barley caused an increase in time of rumination from 3.6 to $6.6 \mathrm{~h} / 24 \mathrm{~h}$.

Manipulation of rumen fermentation has been achieved by several means. The more important of these have been to vary the ratio of hay: concentrate in the food (Bath \& Rook, 1963; Donefer, Lloyd \& Crampton, 1963), grinding of roughages (Rhodes \& Woods, 1962), frequency of feeding (Whitelaw, Eadie, Mann \& Reid, 1972) and level of feeding (Bath \& Rook, I963).

The reason for manipulating the type of rumen fermentation has been quite clear for dairy cows, where the non-glucogenic energy ratio (NGR) of the volatile fatty acids (VFA) has been shown to influence greatly the partition of energy between milkfat production and body-energy gain (McClymont \& Vallance, 1962; Van Soest, r963a; Ørskov, Flatt, Moe, Munson, Hemken \& Katz, 1968). 
The reasons for manipulating rumen fermentation in the instance of growing and fattening animals have been less clear. From stoichiometric relationships the methane production decreases with an increase in the proportion of propionic acid (Hungate, I966) and increases with a high proportion of acetic acid and butyric acid. The inefficient utilization of acetic acid for fattening reported by Armstrong \& Blaxter (1957) has not always been confirmed and more recent evidence (Ørskov \& Allen, 1966; Hovell \& Greenhalgh, 1972) suggests that the utilization depends on the relative proportions in which the different VFAs are absorbed. In experiments in which lambs have been given barley diets, with a consequent high content of propionic acid in the rumen liquor, problems have been encountered with soft subcutaneous fat containing unusually high proportions of odd-numbered $n$-fatty acids and branchedchain fatty acids (Duncan, Ørskov \& Garton, 1972). The association with propionic acid was confirmed in an experiment in which propionate was added to a basal diet (Garton, Hovell \& Duncan, 1972).

The experiments now reported were conducted to examine the effect of the processing of grain on the type of rumen fermentation, on digestibility, on rumination time and on the firmness of subcutaneous fat. A brief account of part of this work has been given (Ørskov \& Fraser, 1972). The results on food utilization will be reported elsewhere (Fraser \& Ørskov, 1973).

\section{MATERIALS AND METHODS}

\section{Expt I}

Animals. Twenty-four entire male lambs, twelve Suffolk $\times$ Scottish Blackface and twelve Suffolk $\times$ North Country Cheviot crosses were randomized within breed to receive two treatments.

Treatments. The treatments consisted of $a d$ lib. feeding on diets consisting of pellets $(7.4 \mathrm{~mm})$ made from either rolled or whole barley with a protein supplement. Half the lambs on each treatment were injected twice weekly with $0.2 \mathrm{ml} / 5 \mathrm{~kg}$ live weight of a vitamin $\mathrm{B}_{12}$ preparation containing $250 \mu \mathrm{g}$ hydroxcobalamin/ml (Neocytamin 250, Glaxo Laboratories, Greenford, Middlesex). The diet contained ( $\mathrm{g} / \mathrm{kg}$ fresh weight) barley 910, white fish meal 75 and limestone 15 , to give $164 \mathrm{~g}$ crude protein $/ \mathrm{kg}$ dry matter. Trace minerals were added to provide (mg/kg diet): $200 \mathrm{MgO}, \mathrm{r}_{50}$ $\mathrm{ZnSO}_{4} \cdot 7 \mathrm{H}_{2} \mathrm{O}, 80 \mathrm{MnSO}_{4} \cdot 4 \mathrm{H}_{2} \mathrm{O}$, $x \mathrm{KI}$ and $0.43 \mathrm{CoSO}_{4} \cdot 7 \mathrm{H}_{2} \mathrm{O}$. Vitamins were added to give $\left(\mathrm{mg} / \mathrm{kg}\right.$ diet): $\mathrm{r}_{5} 5$ retinoyl palmitate, 0.025 cholecalciferol and $20 \mathrm{DL}-\alpha-$ tocopheryl acetate.

\section{Expt 2}

Animals. Twelve female Suffolk $\times$ (Finnish Landrace $\times$ Dorset Horn) lambs were randomized to receive two treatments.

Treatments. The treatments consisted of giving either pellets made from whole barley, as in Expt I, or a loose mixture of whole barley grains with a protein, mineral and vitamin supplement. The ingredients of the diets were similar to Expt I. The trial was divided into four periods with two periods of $a d$ lib. feeding (days 2I-56 and 
$8 \mathrm{I}-98$ ) and two periods (days $\mathrm{I}-20$ and $57-80$ ) where the food intake was restricted to $90 \%$ of estimated maximum.

\section{Expt 3}

Animals. Thirty-six female Suffolk $\times$ (Finnish Landrace $\times$ Dorset Horn) lambs were randomized to twelve treatments.

Treatments. In a $3 \times 2 \times 2$ factorial design, three methods of processing barley, two levels of cobalt supplementation and the effect of intramuscular injections of a cyanocobalamin preparation were investigated. The barley was either incorporated, along with the protein, mineral and vitamin premix, into $7.4 \mathrm{~mm}$ pellets in the whole or rolled form or was given in the whole form as a loose mix with a $4.4 \mathrm{~mm}$ pellet of the protein, mineral and vitamin premix. The premix contained $(\mathrm{g} / \mathrm{kg})$ : white fish meal 800 , limestone 150 , molasses 40 , trace minerals and vitamins 10 , and was incorporated at the rate of $100 \mathrm{~g} / \mathrm{kg}$ diet. Co supplements were 0.43 or $5.3 \mathrm{mg} \mathrm{CoSO}{ }_{4} \cdot 7 \mathrm{H}_{2} \mathrm{O} / \mathrm{kg}$ diet. The vitamin injection (Crookes Vitamins Ltd, Basingstoke, Hants) contained I $\mathrm{mg}$ cyanocobalamin $/ \mathrm{ml}$ and was given at the rate of $0.04 \mathrm{ml} / \mathrm{kg}$ live weight twice each week.

\section{Expt 4}

Animals. Sixty-four Suffolk $\times$ (Finnish Landrace $\times$ Dorset Horn) lambs were used, comprising thirty-two entire males and thirty-two females. The lambs from each sex were randomized to eight treatments.

Treatments. The treatments consisted of ad lib. feeding on either whole barley, maize, oats or wheat in a loose mix or pellets $(7.4 \mathrm{~mm})$ made from the same roughly milled cereals $(5 \mathrm{~mm}$ screen). The protein supplement with trace minerals and vitamins and the level of inclusion in the diet were the same as in Expt 3 and the supplement contained $5.3 \mathrm{mg} \mathrm{CoSO}{ }_{4} \cdot 7 \mathrm{H}_{2} \mathrm{O} / \mathrm{kg}$ diet. As in Expt 3 , the supplement was either pelleted and mixed with the loose whole cereals, or incorporated into the pellets made from the roughly milled cereals. The barley, maize, oats and wheat diets contained, respectively, $169,168,175$ and $168 \mathrm{~g}$ crude protein $/ \mathrm{kg}$ dry matter.

\section{Expt 5}

Animals. Four Suffolk $\times$ (Finnish Landrace $\times$ Dorset Horn) lambs, about 2 months of age, were allocated to receive two treatments in a change-over design during periods of 3 weeks.

Treatments. The two treatments consisted of $a d$ lib. feeding of whole barley in a loose mix or pellets made from whole barley; the diet composition was similar to Expt 3 . At the end of each 3-week period, continuous $48 \mathrm{~h}$ records of jaw movements were made by the modified pneumatic method of Gordon (1955). In this method a protected rubber balloon filled with foam rubber (but not inflated) is held in a harness under the animal's jaw. Pressure waves created by movements of the mandible are carried by rubber tube to a recorder. 


\section{Management}

The lambs used for Expts I-4 were all weaned at 4 weeks of age and at about 6 weeks they were introduced to the experimental treatment. Except for Expt 2, when there were periods of restricted feeding, the food was offered ad lib. At weekly intervals the amounts consumed in the previous week were determined by drying the food residues to constant weight at $100^{\circ}$.

At about $25 \mathrm{~kg}$ live weight the lambs in Expts I, 3 and 4 were placed in metabolism cages for I4 d; during the last $8 \mathrm{~d}(7 \mathrm{~d}$ for Expt 3 ) of which the faeces were collected. The lambs in Expt 2 were kept in metabolism cages and their faeces were collected during the last $8 \mathrm{~d}$ of each feeding period.

In Expt I the lambs were slaughtered when they reached $40 \mathrm{~kg}$ live weight and in Expts 3 and 4 at $35 \mathrm{~kg}$ live weight. Those in Expt 2 were slaughtered when the experiment was completed, at which time they had an average weight of $38 \mathrm{~kg}$.

On the day prior to slaughter at about I I.00 hours samples of rumen contents were obtained by stomach pump; the $\mathrm{pH}$ values were determined and sub-samples obtained for VFA analysis. At slaughter the carcass and liver weights were recorded. The rumen walls were examined for lesions, the results of which, for Expts I, 2 and 3 , have been published (Ørskov, 1973). The firmness of subcutaneous fat was assessed after $24 \mathrm{~h}$ chilling at $\mathrm{I}^{\circ}$; a score of $\mathrm{I}$ was considered the normal and 4 very soft.

In all experiments the diets and faeces were analysed for nitrogen by the Kjeldahl method using the automated equipment described by Davidson, Mathieson \& Boyne (1970). The ash content of the diets and faeces was determined by ashing to constant weight at $600^{\circ}$. VFA were analysed by gas-liquid chromatography employing a flame ionization detector (Fell, Kay, Whitelaw \& Boyne, 1968). Acid-detergent fibre (ADF) was determined by the method of Van Soest $(1963 b)$.

In Expt 3 samples of subcutaneous and perinephric fat were taken for analysis to determine fatty acid compositions, the results of which are given in the subsequent paper (Duncan, Ørskov, Fraser \& Garton, 1974).

The NGR of the VFA was calculated from the expression $(A+2 B) \div P$, where $A$, $B$ and $P$ were the proportions of acetic, butyric and propionic acid respectively.

\section{RESULTS}

Expt I

The results of Expt $\mathrm{I}$ are given in Table $\mathrm{I}$. The apparent digestibility of both dry and organic matter was increased $(P<0.01)$ when the pellets were made from whole rather than rolled barley. There were no significant differences in rumen $\mathrm{pH}$ or the NGR of the VFAs. The liver weight was greater for those animals that had received pellets based on whole barley. Fat firmness did not differ between treatments and the vitamin $B_{12}$ injections had no effect. 
Table 1. Expt 1. The effect of giving pellets made from rolled or whole barley in lambs' diets on digestibility, rumen $p H$, non-glucogenic energy ratio* $(N G R)$ of volatile fatty acids (VFA), liver weight, and firmness of subcutaneous fat.

(Mean values for twelve observations)

Digestibility ratios

$\begin{array}{lcccccc}\begin{array}{c}\text { Treatment } \\ \text { of barley }\end{array} & \begin{array}{c}\text { Dry } \\ \text { matter }\end{array} & \begin{array}{c}\text { Organic } \\ \text { matter }\end{array} & \text { Rumen pH } & \text { NGR } & \begin{array}{c}\text { Liver } \\ \text { weight } \\ (\mathrm{g})\end{array} & \begin{array}{c}\text { Fat } \\ \text { firmness } \\ \text { score† }\end{array} \\ \text { Pelleted rolled } & 0.753 & 0.778 & 5.0 & 1.30 & 975 & 2.9 \\ \text { Pelleted whole } & 0.778 & 0.804 & 5.3 & 1.29 & 1052 & 2.6 \\ \text { SE of mean } & 0.004 & 0.004 & 0.2 & 0.33 & 20 & 0.2\end{array}$

* $N G R=(A+2 B) \div P$, when $A, B$ and $P$ are the proportions of acetic, butyric and propionic acids in the total VFA of the rumen.

$\dagger$ I normal, 4 very soft.

Table 2. Expt 2. Effect of feeding lambs ad lib. on loose whole or pelleted whole barley on digestibility, liver weight and firmness of subcutaneous fat

(Mean values for twelve observations)

Digestibility ratios

Diet

Loose

Pelleted

SE of mean

$\begin{array}{cccc}\text { Dry matter } & \text { Organic matter } & \text { Liver weight }(\mathrm{g}) & \text { Fat firmness score* } \\ 0.780 & 0.801 & 703 & 2.0 \\ 0.767 & 0.801 & 867 & 3.6 \\ 0.005 & 0.004 & 41 & 0.4\end{array}$

* I normal; 4 very soft.

Table 3. Expt 2. Effect of feeding lambs on loose whole or pelleted whole barley on rumen $\mathrm{pH}$ and type of rumen fermentation

(Mean values for six observations)

Proportion in rumen fluid ( $\mathrm{mmol} / \mathrm{mol}$ )

$\begin{array}{lcccccccc}\text { Diet } & \text { pH } & \begin{array}{c}\text { Acetic } \\ \text { acid }\end{array} & \begin{array}{c}\text { Propionic } \\ \text { acid }\end{array} & \begin{array}{c}\text { Iso- } \\ \text { butyric } \\ \text { acid }\end{array} & \begin{array}{c}\text { Butyric } \\ \text { acid }\end{array} & \begin{array}{c}\text { Iso- } \\ \text { valeric } \\ \text { acid }\end{array} & \begin{array}{c}\text { Valeric } \\ \text { acid }\end{array} & \begin{array}{c}\text { Caproic } \\ \text { acid }\end{array} \\ \text { Loose } & 6 \cdot 2 & 531 & 336 & 22 & 70 & 21 & 28 & 6 \\ \text { Pelleted } & 5.2 & 394 & 439 & 6 & 126 & 10 & 24 & 11 \\ \text { SE of mean } & 0.1 & 26 & 22 & 3 & 24 & 4 & 4 & 4\end{array}$

Expt 2

There were no significant differences between periods in apparent digestibilities of dry and organic matter and in Table 2 only the combined means for both ad lib. feeding periods have been given. Liver weight and the assessment of fat firmness are also included. There were no significant differences in apparent digestibilities of dry and organic matter due to processing. The liver weights were greatest for those lambs that had received the pelleted $\operatorname{diet}(P<0.05)$ and the subcutaneous fat was firmer in those that had received the loose whole barley $(P<0.05)$.

The rumen $\mathrm{pH}$ and VFA proportions are given in Table 3. The $\mathrm{pH}$ was 
Table 4. Expt 3. Effects of processing of barley in lambs' diets on digestibility, rumen $p H$ non-glucogenic energy ratio* $(N G R)$ of volatile fatty acids (VFA), liver weight and firmness of subcutaneous fat

(Mean values for twelve observations)

\begin{tabular}{|c|c|c|c|c|c|c|c|}
\hline \multirow[b]{2}{*}{$\begin{array}{c}\text { Treatment } \\
\text { of barley }\end{array}$} & \multicolumn{2}{|c|}{ Digestibility ratios } & \multirow[b]{2}{*}{$\begin{array}{c}\text { Intake ( } \mathrm{g} \\
\text { dry matter } / \\
\left.\mathrm{kg}^{0 \cdot 75}\right)\end{array}$} & \multirow[b]{2}{*}{$\begin{array}{c}\text { Rumen } \\
\mathrm{pH}\end{array}$} & \multirow[b]{2}{*}{ NGR } & \multirow[b]{2}{*}{$\begin{array}{l}\text { Liver } \\
\text { weight } \\
\text { (g) }\end{array}$} & \multirow[b]{2}{*}{$\begin{array}{c}\text { Fat } \\
\text { firmness } \\
\text { scoret }\end{array}$} \\
\hline & $\begin{array}{c}\text { Dry } \\
\text { matter }\end{array}$ & $\begin{array}{c}\text { Organic } \\
\text { matter }\end{array}$ & & & & & \\
\hline Loose whole & 0.774 & 0.810 & $67 \cdot 0$ & $6 \cdot I$ & $2 \cdot 14$ & 673 & $2 \cdot 1$ \\
\hline Pelleted whole & 0.764 & 0.793 & $71 \cdot 6$ & $5 \cdot 2$ & 1.66 & 788 & $2 \cdot 8$ \\
\hline Pelleted rolled & 0.777 & 0.808 & $67 \cdot 1$ & $5 \cdot 2$ & $r \cdot 5 \mathrm{I}$ & 728 & 3.1 \\
\hline SE of mean & 0.010 & 0.011 & $2 \cdot I$ & 0.1 & 0.20 & 29 & 0.2 \\
\hline
\end{tabular}

- $N G R=(A+2 B) \div P$, where $A, B$ and $P$ are the proportions of acetic, butyric and propionic acids in the total VFA of the rumen.

+ I normal, 4 very soft.

Table 5. Expt 4. Effect of processing of different cereals in lambs' diets on rumen $p H$, type of rumen fermentation, and concentration of volatile fatty acids $(V F A)$, and liver weight

\begin{tabular}{|c|c|c|c|c|c|c|c|c|c|}
\hline \multirow[b]{2}{*}{$\begin{array}{l}\text { Cereal } \\
\text { and } \\
\text { treatment }\end{array}$} & \multirow[b]{2}{*}{$\begin{array}{l}\text { Rumen } \\
\text { pH }\end{array}$} & \multirow[b]{2}{*}{$\begin{array}{l}\text { VFA con- } \\
\text { centration in } \\
\text { rumen } \\
\text { (mequiv./I) }\end{array}$} & \multicolumn{6}{|c|}{$\begin{array}{l}\text { Proportions of individual VFA in rumen fluid } \\
(\mathrm{mmol} / \mathrm{mol})\end{array}$} & \multirow[b]{2}{*}{$\begin{array}{l}\text { Liver } \\
\text { weight } \\
\text { (g) }\end{array}$} \\
\hline & & & $\begin{array}{c}\text { Acetic } \\
\text { acid }\end{array}$ & $\begin{array}{l}\text { Propi- } \\
\text { onic } \\
\text { acid }\end{array}$ & $\begin{array}{l}\text { Iso- } \\
\text { butyric } \\
\text { acid }\end{array}$ & $\begin{array}{c}\text { Butyric } \\
\text { acid }\end{array}$ & $\begin{array}{l}\text { Iso- } \\
\text { valeric } \\
\text { acid }\end{array}$ & $\begin{array}{c}\text { Valeric } \\
\text { acid }\end{array}$ & \\
\hline \multicolumn{10}{|l|}{ Barley } \\
\hline LW & $6 \cdot 4$ & 86 & 525 & 301 & 20 & I 20 & 16 & I 8 & 735 \\
\hline PG & $5 \cdot 4$ & 102 & $45^{\circ}$ & 453 & 3 & 70 & 7 & I 7 & 767 \\
\hline \multicolumn{10}{|l|}{ Maize } \\
\hline LW & $6 \cdot I$ & 84 & 472 & $3^{87}$ & I I & 88 & 13 & 29 & 859 \\
\hline PG & $5 \cdot 2$ & 90 & $4^{13}$ & 432 & IO & 100 & 15 & $3 I$ & 805 \\
\hline \multicolumn{10}{|l|}{ Oats } \\
\hline LW & $6 \cdot 7$ & 65 & 650 & I 86 & 16 & II7 & 27 & 5 & $53 \mathrm{I}$ \\
\hline PG & $6 \cdot I$ & 73 & 532 & 375 & 20 & 54 & 6 & 13 & 644 \\
\hline \multicolumn{10}{|l|}{ Wheat } \\
\hline LW & 5.9 & 78 & 523 & 322 & 28 & 86 & 8 & 33 & 807 \\
\hline PG & 5.0 & 100 & 342 & 426 & 23 & 160 & 12 & 37 & 844 \\
\hline SE of mean & 0.14 & II & 24 & 32 & 7 & 20 & 4 & 5 & 32 \\
\hline
\end{tabular}

LW, loose, whole; PG, pelleted, ground.

significantly higher in lambs given the loose whole barley diets $(P<0.01)$, while the proportion of acetic acid was greater $(P<0.01)$ and that of propionic acid was smaller $(P<0.01)$. The differences between the other VFA were not significant.

Expt 3

The apparent digestibility, rumen $\mathrm{pH}, \mathrm{NGR}$, liver weight and fat firmness are given in Table 4. The level of cobalt supplementation or of vitamin $B_{12}$ injection did not affect the measurements given in Table 4 , and the results have been pooled according to treatment of the cereals. 
Table 6. Expt 4. Effect of processing of different cereals in lambs' diets on digestibility of dry matter, organic matter, acid-detergent fibre $(A D F)$ and nitrogen

(Mean values for four observations)

\begin{tabular}{|c|c|c|c|c|c|}
\hline \multirow{2}{*}{$\begin{array}{l}\text { Cereal and } \\
\text { treatment }\end{array}$} & \multirow{2}{*}{$\begin{array}{c}\text { Dry matter } \\
\text { intake } \\
\left(\mathrm{g} / \mathrm{kg}^{0-75}\right)\end{array}$} & \multicolumn{4}{|c|}{ Digestibility ratios } \\
\hline & & Dry matter & Organic matter & ADF & $\mathbf{N}$ \\
\hline \multicolumn{6}{|l|}{ Barley } \\
\hline$L W$ & $79 \cdot 6$ & $0.78 \mathrm{r}$ & 0.811 & 0.472 & $0.7 \times 5$ \\
\hline PG & $80 \cdot 0$ & 0.737 & 0.772 & 0.331 & 0.658 \\
\hline \multicolumn{6}{|l|}{ Maize } \\
\hline $\begin{array}{l}\text { LW } \\
\text { PG }\end{array}$ & $\begin{array}{l}72 \cdot 0 \\
78 \cdot 5\end{array}$ & $\begin{array}{l}0.804 \\
0.789\end{array}$ & $\begin{array}{l}0.843 \\
0.821\end{array}$ & $\begin{array}{l}0.55 I \\
0.399\end{array}$ & $\begin{array}{l}0.752 \\
0.699\end{array}$ \\
\hline \multicolumn{6}{|l|}{ Oats } \\
\hline LW & $79 \cdot 6$ & 0.657 & 0.699 & 0.212 & 0.777 \\
\hline PG & $76 \cdot 2$ & $0.63 \mathrm{I}$ & 0.675 & 0.136 & 0.766 \\
\hline \multicolumn{6}{|l|}{ Wheat } \\
\hline LW & 79.9 & 0.807 & 0.827 & 0.320 & 0.705 \\
\hline PG & $73 \cdot 3$ & 0.834 & 0.866 & 0.398 & 0.759 \\
\hline SE of mean & $6 \cdot I$ & 0.013 & 0.012 & 0.048 & 0.026 \\
\hline
\end{tabular}

LW, loose, whole; PG, pelleted, ground.

None of the differences in digestibility was significant; the rumen $\mathrm{pH}$ was significantly higher when loose whole barley was given $(P<0.001)$. The weight of the liver was less $(P<0.05)$ and the fat was firmer $(P<0.05)$ in these animals. The differences between loose whole and the two pelleted barley diets in the NGR approached significance $(0.05<P<0.1)$.

\section{Expt 4}

The effect of grinding and pelleting the different cereals on rumen $\mathrm{pH}, \mathrm{VFA}$ and liver weights are given in Table 5. The $\mathrm{pH}$ was significantly lower $(P<0.00 \mathrm{r})$ and the concentration of VFA significantly higher $(P<0.05)$ when the diets were pelleted. The proportion of acetic acid was smaller $(P<0.001)$ and the proportion of propionic acid greater when the diets were pelleted $(P<0.01)$.

There were also differences between cereals in the ruminal $\mathrm{pH}(P<0.00 \mathrm{I})$ and the proportion of acetic $(P<0.001)$ and propionic acids $(P<0.001)$ in the rumen liquor. These differences are mainly due to the extreme values found with the oat diets. The molar proportion of valeric acid was smaller with the oat diets $(P<0.01)$. Analysis of the molar proportions of butyric acid showed significant cereal $v$. processing interaction $(P<0.0$ I) whereby with barley and oats the proportion of butyric acid was greatest when loose whole grain diets were given. With wheat, in contrast, the proportion of butyric acid was greatest when the diet was pelleted.

The intake, digestibilities of dry matter, organic matter, $\mathrm{ADF}$ and $\mathrm{N}$ are given in Table 6. There were no differences in dry matter intake, but for digestibilities of dry matter, organic matter and ADF there were highly significant $(P<0.001)$ differences 
Table 7. Comparison of chewing behaviour when lambs were given diets based on loose whole barley or pelleted whole barley

(Mean values for four observations)

$\begin{gathered}\text { Treatment of } \\ \text { barley }\end{gathered}$
Loose
Pelleted
SE of mean

\begin{tabular}{|c|}
\hline $\begin{array}{l}\text { Rumination } \\
\text { time } \\
(\min / 24 h)\end{array}$ \\
\hline $\begin{array}{l}402 \\
216\end{array}$ \\
\hline $4 I \cdot 5$ \\
\hline
\end{tabular}

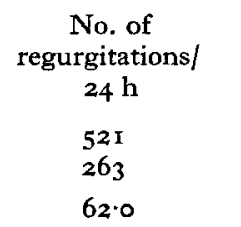

$\begin{gathered}\text { Periods of } \\ \text { rumination/ } \\ 24 \mathrm{~h}\end{gathered}$
31
23
3.7

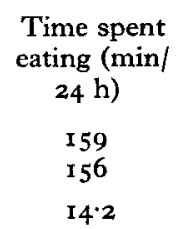

between the cereals in that the oats were less digestible than the other diets. The apparent digestibility of $\mathrm{N}$ was higher for oats than for barley $(P<0.05)$.

There were no significant effects of pelleting on apparent digestibility when all diets were included, though with ADF the differences approached significance $(P<O \cdot I)$. The apparent digestibilities of dry matter and ADF, however, showed that there tended to be $(P<O \cdot I)$ an interaction between pelleting and the source of cereal which reached significance when organic matter was considered $(P<0.05)$. This arose from a significant depression in the apparent digestibilities of the dry and organic matter of barley $(P<0.05)$ when it was pelleted. With wheat, on the other hand, the reverse was true, the apparent digestibility of organic matter being significantly increased by pelleting $(P<0.05)$. The apparent digestibility of ADF of both barley and maize was depressed by pelleting $(P<0.05)$, and there was a non-significant increase with wheat. There were no significant differences in $\mathrm{N}$ digestibility due to processing.

The examinations of the lesions on the rumen wall showed that with pelleted barley, wheat and maize there was extensive ruminitis and clogging of papillas. With the whole grains no pathological changes were observed: the rumen papillas were flat and well separated. This was also the situation for the pelleted oat diet.

\section{Expt 5}

The recordings of jaw movements are given in Table 7 . Significantly more time was spent ruminating with loose whole grains $(P<0.01)$ than with pelleted whole grain and more rumination boluses were regurgitated $(P<0.001)$. This was not due to increased intake since the mean dry matter intakes $(\mathrm{g} / \mathrm{d})$ were 898 and 940 for the loose whole and pelleted whole diets respectively. There were no significant differences in eating time or in the number of periods of rumination.

\section{DISCUSSION}

Effect of processing of cereals on type of rumen fermentation and digestibility

The results show that processing cereals in different ways causes alterations in the type of rumen fermentation. The range in type of fermentation obtained with different cereals and processing methods is very considerable. At one extreme, whole oats are fermented to give VFA proportions characteristic of the fermentation of roughage and, 
at the other, pelleted wheat and maize are fermented to give a product in which the proportion of propionic acid is greater than that of acetic acid. These changes due to processing for each cereal are accompanied by substantial changes in pH. It is probable that the maintenance of a higher $\mathrm{pH}$ is causally related to the establishment of a ruminal microflora which results in a higher acetic acid type of rumen fermentation. When whole grain rather than processed grain is given, the conditions in the rumen become more stable. This is supported by studies in similar lambs in unpublished work by J. M. Eadie \& E. R. Ørskov, who showed that rumen ciliate protozoa survived or could be established in substantial numbers when whole barley was given; neither survival nor establishment could take place when pelleted grain was given, and it was also shown that the diurnal variation in the $\mathrm{pH}$ was much less with loose whole than with pelleted whole barley. The feeding of loose whole grains had further desirable effects on the rumen wall as the pathological changes generally associated with pelleted grain feeding were completely eliminated. The observations with wheat and maize are thus similar to the results previously published for barley (Ørskov, I973). Unpublished work by S. O. Mann \& E. R. Ørskov has shown that the number of cellulolytic bacteria was greater when the diet was made with whole rather than with pelleted barley and indeed this may well be responsible for the small increase in the digestibility of the fibre fraction noted in Expt 4 . With sheep this is of particular importance since there was no reduction in total digestibility. In fact, in both Expts 2 and 4 there were small increases in digestibility when barley was given whole and loose.

Since there was no reduction in digestibility and rates of intake and also little or no change in sites of digestion (E. R. Ørskov \& C. Fraser, unpublished results), the increase in rumen $\mathrm{pH}$ with feeding of whole grains must have been due to causes other than a lower production of VFA. The doubling of rumination time from abnormally low to that which is normal for roughage feeding (Gordon, I968) must have been a major contributor since it would be expected to greatly enhance the return of saliva to the rumen (Kay, I966) and so influence the buffering capacity. The resting flow of saliva may also have been greater since Putnam, Yarns \& Davis (1966) found that the resting flow of saliva was reduced with feeding of pelleted roughage.

The change in buffering capacity cannot, however, explain the reduction in the concentration of VFA. This is particularly interesting since the rate of absorption is greatest at low $\mathrm{pH}$, as the VFA are absorbed as the free acids (Stevens, 1970). In each dietary situation an equilibrium is apparently established between rate of production and rate of absorption which in turn is likely to be influenced by the $\mathrm{pH}$, the distance to the absorption area and the surface area available for absorption. The greatest change noted here, apart from $\mathrm{pH}$, was that of the surface area for absorption which, although not measured, must have been several times greater with the feeding of whole grains than with pelleted grains, since no thickening of the rumen wall had taken place and there was no clogging of the rumen papillas.

\section{Effect of vitamin $B_{12}$ and Co on fat firmness}

The failure of the injections of vitamin $B_{12}$ in Expts $I$ and 3 and of the addition of Co in Expt 3 to influence firmness of subcutaneous fat is discussed in more detail 
in the subsequent paper, with reference to the lack of evidence of vitamin $B_{12}$ being the limiting factor in propionate metabolism by the liver (Duncan et al. 1974).

\section{Effect of processing on liver weight and fat firmness}

The observation in Expt 2 that the firmness of the subcutaneous fat was considerably improved when whole barley was given was confirmed in Expt 3 and supported by the changes in the fatty acid composition as discussed in the subsequent paper by Duncan et al. (1974). The changes in the fatty acid composition were undoubtedly a result of the changes in the proportions of VFAs produced and possibly also of a reduction in the peak concentrations associated with feeding, since with feeding of loose whole barley the rumen conditions are more stable, as referred to earlier. Of the methods examined so far, only a reduction in the proportion of propionic acid proved an effective means of reducing the soft fat problems in the lambs.

The livers of the lambs given whole grain were not only lighter, but also appeared to be more soft and pliable; whether this is associated with glycogen storage is not known, though it is a possibility. With feeding of propionate Hovell (1972) also found a greater liver weight in comparison with feeding of acetate, which suggests that the changes noted on processing grain are related to changes in the end-products of the ruminal fermentation.

The authors express their gratitude to Mr Ian McDonald for the statistical analysis of the results and to Mr J. C. Gill for care of the experimental animals. We wish to thank Mr R. Smart for the chemical analyses and Mr R. S. Reid for the gas-chromatographic separation of the volatile fatty acids.

\section{REFERENCES}

Armstrong, D. C. \& Blaxter, K. L. (1957). Br. 7. Nutr. Ir, 413.

Bath, 1. H. \& Rook, J. A. F. (1963). F. agric. Sci., Camb. 6r, 341.

Davidson, I., Mathieson, J. \& Boyne, A. W. (1970). Analyst, Lond. 95, 181.

Donefer, E., Lloyd, L. E. \& Crampton, E. W. (1963). F. Anim. Sci. 22, 425.

Duncan, W. R. H., Orskov, E. R. \& Garton, G. A. (1972). Proc. Nutr. Soc. 31, 20 A.

Duncan, W. R. H., Ørskov, E. R., Fraser, C. \& Garton, G. A. (1974). Br. \%. Nutr. 32, 7 r.

Fell, B. F., Kay, M., Whitelaw, F. G. \& Boyne, R. (1968). Res. vet. Sci. 9, 458.

Fraser, C. \& Ørskov, E. R. (1973). Anim. Prod. 18, 85 .

Garton, G. A., Hovell, F. D. \& Duncan, W. R. H. (I 972). Br. F. Nutr. 28, 409 .

Gordon, J. G. (1955). Rumination in the sheep. PhD Thesis, University of Aberdeen.

Gordon, J. G. (I968), Wld Rev. Nutr. Diet. 9, 25 I.

Hovell, F. D. (1972). The utilization of salts of volatile fatty acids by growing lambs. $\mathrm{PhD}$ Thesis, University of Aberdeen.

Hovell, F. D. \& Greenhalgh, J. F. D. (1972). Proc. Nutr. Soc. 31, 68 A.

Hungate, R. E. (1966). The Rumen and Its Microbes. London, New York: Academic Press.

Kay, R. N. B. (1966) Wld Rev. Nutr. Diet. 6, 292.

McClymont, G. L. \& Vallance, S. (1962). Proc. Nutr. Soc. 21, xli.

Ørskov, E. R. (1973). Res. vet. Sci. I4, r ro.

Ørskov, E. R. \& Allen, D. M. (1966). Br. J. Nutr. 20, 5 r9.

Ørskov, E. R., Flatt, W. R., Moe, P. W., Munson, H. W., Hemken, R. W. \& Katz, I. (1968). Br. $尹$. Nutr. 23, 443.

Ørskov, E. R. \& Fraser, C. (1972). Proc. Nutr. Soc. 31, rooA. 
Vol. 32

Putnam, P. A., Yarns, D. A. \& Davis, R. E. (1966). F. Anim. Sci. 25, i 176.

Rhodes, R. W. \& Woods, W. (1962). F. Anim. Sci. 21, 483 .

Stevens, C. E. (1970). In Physiology of Digestion and Metabolism in the Ruminant p. Ior [A. T. Phillipson, editor]. Newcastle upon Tyne: Oriel Press.

Van Soest, P. J. (1963a). F. Dairy Sci. 46, 204.

Van Soest, P. J. (1963b). F. Ass. off. agric. Chem. 46, 829.

Whitelaw, F. G., Eadie, J. M., Mann, S. O. \& Reid, R. S. (1972), Br. F. Nutr. 27, 425. 